\title{
A cybernetic future for small-scale fisheries
}

\author{
Camilla Brattland ${ }^{1,2}$
}

\author{
Correspondence: \\ camilla.brattland@uit.no \\ ${ }^{1}$ Norwegian Institute for Cultural \\ Heritage Research (NIKU), High \\ North Department, Tromsø, Norway \\ ${ }^{2}$ UiT- The Arctic University of Norway, \\ Centre for Sami Studies, Tromsø, \\ Norway
}

\begin{abstract}
This article discusses the future of indigenous Sami fisheries in cybernetic fisheries systems characterized by increasing effectivization and industrialisation. It empirically investigates the past and present development of a small-scale fjord fishery in Porsanger, northern Norway, which has been a major part of the material basis for indigenous Sami culture and settlements in the area. The article utilises historical vessel registries and fishers' vessel career narratives from the post-war period to the present to analyse how relations between vessels, fishers, technology, ecology and the society at large have changed, and to what extent the small-scale fishery of the past seems to be disappearing in a fisheries system characterised by increasing cyborgization especially in the period after 1990. The main finding is an identification of diverse ways of organising the small-scale fishery in Porsanger in the past which had an influence on which types of vessels and fishers stayed put in the post-1990 period. This process was influenced not only by the introduction of the vessel quota system but also by ecological conditions and changing social and material relations in the local fisheries. In particular, the fishery with small open vessels with outboard engines experienced a golden age prior to the 1990s, but then abruptly decreased due to a combination of ecological conditions and management interventions. The fishery with decked, coastal fishing vessels however remained relatively stable throughout the period and continues to dominate the Porsanger small-scale fishery. The case study demonstrates diverse and flexible ways of organising relations in a coastal Sami community over time, thus implying that a cybernetic future may be possible also for small-scale fisheries.
\end{abstract}

Keywords: Small-scale fisheries; Indigenous rural areas; Cyborgization; Vessel careers; Northern Norway

\section{Introduction}

In northern Norway, traditional small-scale fisheries seem faced with eradication in the face of what Johnsen (2013) describes as a process of cyborgization that transforms fisheries systems and results in 'an increasingly efficient and self-controlled, but more depopulated, fishing industry' (ibid.p. 13). Whether there at all exists a future for coastal fisheries as a livelihood not only for professional fishers aboard high-tech fishing machines thus seems uncertain. For the indigenous coastal Sami fjord fishers the future looks especially bleak, as the number of fishers in Sami settlement areas are dwindling and small-scale fisheries today make up only a fraction of what it once used to provide in terms of income and as a culturally and economically important livelihood for the Sami people (NOU 2008:5). However, rather than accepting the eradication of small-scale fisheries as an investable outcome of the processes of cyborgization,

(C) 2014 Brattland; licensee Springer. This is an Open Access article distributed under the terms of the Creative Commons Attribution License (http://creativecommons.org/licenses/by/4.0), which permits unrestricted use, distribution, and reproduction in any medium, provided the original work is properly credited. 
this article asks how small-scale fisheries are being transformed and what they might look like in the future. This implies investigating the projected development of cybernetic fisheries systems, as well as asking what the differences are between the way small-scale fisheries were organised in the past and what they might be like as part of a cybernetic fisheries system. This article discusses what an indigenous Sami cybernetic fisheries system might look like, based on an empirical case study of the development of an indigenous Sami small-scale fjord fishery in Porsanger, northern Norway.

Small-scale fisheries adaptations in northern Norwegian fjords have often been the object of research and much debate since the introduction of quotas and access limitations at the beginning of the 1990s (i.e. Bjørklund 1991; Jentoft 1998; Nilsen 1998; Eythorsson 1993; 2008; Lillevoll 1998; Brattland 2012). Conflicts between fjord fishing and active gear types such as Danish seine vessels escalated and became hotly debated in the 1980s as part of processes aimed at revitalizing Sami culture and political standing in Norwegian society after over 150 years of Norwegian assimilation policies (Eythorsson 1993; Minde 2005). The injustice done to Sami fjord fishers following the introduction of the individual vessel quota (IVQ) system to Norwegian coastal fisheries in 1990 was one of the first cases that the newly established representative body for the Sami, the Sami Parliament, discussed with the Norwegian government (see Davis and Jentoft 2001; Brattland 2012; Søreng 2013 and Søreng 2008). Increased fish mortality in the Barents Sea cod stock was the main reason for closing the fjord and coastal fisheries on April $18^{\text {th }} 1989$, before many fjord fishers had started their main season (Jentoft 1993). The Sami Parliament argued that because small-scale fjord fishers had reduced mobility compared to other fishers, and because of an unexpected ecological crisis (known as an 'invasion of seals') which reduced fjord fishers' cod catches prior to 1990, the Sami were unduly affected by the state management system and should have their indigenous fishing rights recognised (Sami Parliament 2004). A Coastal Fishing Commission set up by the government to investigate the right to fish off the Finnmark coast for Sami and others (NOU 2008:5) documented that, compared to typical coastal fishing communities, Sami fjord communities received a very low number of vessel quotas in 1990 relative to the number of vessels registered (Maurstad 2000).

The predicament of the Sami fjord fishers following 1990 was part of larger societal developments and changes in the Norwegian fishing industry and management system that were not particular to Sami fjord fisheries. The state and the main organization of the fishers, the Norwegian Fishing Association, had since the Second World War led a policy of building up the fishing industry through favourable conditions for the fishers and state subsidies. This led to an enormous growth in the fishing fleet and increase in capture capacity, which was followed by overfishing of the total allowable catch (TAC) that preceded the 1989 closure, cuts in state subsidies and introduction of market liberalism. The Norwegian government currently leads a policy of securing small-scale fjord and coastal fisheries in coastal communities, especially as 'the material basis for Sami culture' (Marine Resource Act 2009). Most recently this policy resulted in legislation of the right to fish for fishers with vessels below 11 meters in Sami settlement areas (Deltakerloven 1999 (Act of participation in the fisheries), § 21), followed by allocation of higher cod quotas to the vessels in this area. The policy is based on an image of the Sami small-scale fishery as being inherently small in scale, and thus in need of positive management measures, which have been implemented in Norwegian fisheries management since the 
beginning of the 1990s (Brattland 2012). The introduction of the vessel quota system in 1990 affected all fishers, and represents a turning point in the history of Norwegian as well as Sami fisheries. Many would argue that this represented the end of the traditional Sami small-scale fisheries adaptation, which will be investigated in the next sections. First, however, a closer inspection of the larger processes of change, and their apparent outcomes, affecting coastal small-scale fisheries during the latest decades will be conducted, with a focus on the concept of cyborgization of fisheries systems.

\section{Towards cyborgization of the fisheries}

According to Johnsen et al. (2009a, 2009b), North Atlantic fisheries have since the Second World War, and increasingly since the 1990s, been characterized by processes of cyborgization. These transformative processes can be seen in the way fisheries governance is changing, as well as through changes in routines, mechanisms and the way relations between materials like fishing gear and equipment are organised. Johnsen et al. (2009a, 2009b) describe three different modes in this process, where the relations between the parts constituting fisheries assemblages change over time. These are the organic, mechanistic and cybernetic modes, all consisting of assemblages of gear, vessel, crew and work processes, but in different relations to each other as fisheries change in character over time. In contrast to the cybernetic system, in the organic mode at the beginning of the 1900s there was an affective and closer relationship between the fisher, the hook and the line and his boat (Johnsen et al. 2009a, 2009b). The organic association, based on anthropological characterizations of 'the traditional organisation of fishing communities associated with the pre- and early post World War II period' (Johnsen et al. 2009a, 2009b:67), is by many also characterized as 'adaptive and resilient for societies dealing with unstable environments' (ibid. p. 68). Increasing mechanisation from the 1920 s to the turn of the century still allowed for organic, affective relations between the fisher and the fish, with machines increasing the efficiency of the fisher. Vessels are no longer made of wood, and organic relations are increasingly mechanised with the use of electronic equipment and echo sounders, radars and computer mapping software.

The more radical change after the millennium into cybernetic systems can be seen through analysis of how the fishery industry has developed (Johnsen et al. 2009a, 2009b). In particular, fishing vessels can be thought of as effective harvest organizations which are integrated in larger networks. The IVQ system is part of this process, which transforms fish into transferable property and integrates the fish and fisher more tightly into larger corporate and financial networks' (Johnsen et al. 2009a, 2009b:70). Even small-scale coastal fishing vessels are transformed into technologically sophisticated killing-fish machines or 'fishing cyborgs', and fishers are increasingly embedded in a position as 'robo fishers' together with machines in fisheries management systems with cybernetic characteristics. This is among other things evidenced by the fact that capture capacity continues to increase in the fishing fleet, while the number of fishers have decreased in the period between 1983 and 2001 (Standal and Aarset 2002; Johnsen 2005). Based on examples from Newfoundland and Norwegian fishers, it is argued that fishers who successfully make the transition from mechanistic to cybernetic fisheries associations adapt by acquiring new knowledge, change social relations, use new technology and integrate resource management into their own practices (Johnsen et al. 
2009a, 2009b). When fishers switch from old to new modes not only vessels but also fishers themselves and their knowledge undergoes changes. 'Whereas in the past we could talk about human fishers with individual fishing knowledge, more and more of the knowledge is now embedded in machinery, organizations, and systems rather than in the individual fisher' (Johnsen et al. 2009a:24).

The cyborgization approach to fisheries is inspired by actor network theory (ANT) (Latour 2005) in its relational approach to the study of fisheries networks, where Haraway's (1997) concepts of the cyborg as a hybrid being with both organic and cybernetic parts and techno-scientific systems are central. From a Latourian perspective, it is not vessels and fishers alone that fish, but assemblages of fishers, vessels, fish, control systems, and so on that actually practice fisheries. While accepting that governance systems with cybernetic forms of organization cause changes in these assemblages (Johnsen et al. 2009a), I question the idea that present fishing assemblages are the result of an evolution from an organic past to a cybernetic present. Although Johnsen et al. (2009a, 2009b) underline that the three types of fisheries associations are ideal types, they are still narrated as if the only path towards survival in fisheries is to evolve by 'accepting some substantial integration into and development towards new and more cybernetic fishing organizations' (Johnsen et al. 2009a, 2009b:71). Is this what is happening also in the case of Sami fisheries, and what does this imply for the survival of traditional small-scale fisheries in general? Instead of evolution towards a 'pure' cybernetic future, I would like to believe that the present governance changes in fisheries create a more heterogeneous network of relations where different forms of assemblages are allowed to exist in diverse and hybrid forms. Latour (1993) for instance points out that it is exactly through acts of separation, that hybrid mixtures between categories that are ideally kept apart are created, in this case the 'pure' modes of fisheries associations. What kind of alternative and diverse fisheries associations and trajectories of development can be discerned in the Sami fisheries context?

Sami fisheries have in general been researched as a rather homogenous group of small-scale fishers and farmers, in line with the thinking of Ottar Brox, who argued that a special northern Norwegian rural fisher-farmer adaptation had developed as a result of late modernisation occurring in the 1960s and 1970s (Brox 1969; 1984). In the post1980 political context of Sami revitalization, Sami fisheries were generally researched within a human ecology and 'peasant mode of production' perspective (Chayanov 1966), where Brox' line of thinking was combined with the idea of indigenous cultures' sustainable adaptation to the environment. In the post-war Norwegian society where building of the welfare state and national economic growth went hand in hand with rural outmigration and flight from agriculture (Hidle et al. 2006), the coastal Sami fisher-farmer adaptation was however practically gone by the late 1980s. From this point of view, the prevalence of small vessels, conventional gear, and moderate fishing effort among Sami fjord fishers prior to 1989, and their disappearance in the following years, was interpreted as a result of the destructive effects of Western modernization and global capitalism on a resilient indigenous culture (i.e. Bjørklund 1991; Nilsen 1998). The introduction of the vessel quota system and the introduction of a liberalist economy has especially been blamed for the demise of Sami small-scale fisheries. A rather uniform and homogenous picture of a resilient, but disappearing culture has been painted (but see Broderstad and Eythórsson 2014), which makes it hard to discover alternative forms of 
transformation and future development trajectories for Sami communities. Since emphasis has been placed on external pressures such as changing management policies and economic liberalisation, little focus has been directed towards internal social and material forces of change within Sami communities, or the status of fjord ecosystems over time. Some of the same critique can also be directed towards the evolutionary character of the cyborgization process, to which I will return later. The task for the next sections is to investigate social, material and ecological transformations in a small-scale fishery during the post-war period in a Sami community, whether it conforms with the narratives described so far, and what its future may look like.

\section{Mapping small-scale fishing assemblages in Porsanger}

This article makes use of the Porsanger fjord fisheries as a case (Yin 2009) to empirically investigate transformation of small-scale fisheries through following relations between fishers and vessels in small-scale fishing assemblages over time. The Porsanger fjord is one of the longest fjords in Finnmark and located close to the North Cape which is the northernmost point in Norway at 71 degrees north. Its trilingual population of around 3500 inhabitants is located in the centre Lakselv and in small villages and towns on the western side of the fjord. Although fisheries in the Porsanger fjord have not been as abundant as on fishing fields off the Finnmark coast, the industry supported four fish receiving stations and employed over 150 fishers (of a population of around 4000 inhabitants in 1970) until the middle of the 1980s, when Nilsen (1998) characterised the fjord fishery as rather industrialised compared to other fjord areas. From the late 1960s onwards, the local fjord fishers had experienced increasing conflicts with vessels using mobile gear such as Danish seine and saithe purse seiners. Fishers from Porsanger had already from the beginning of the century complained of seiners emptying the fjord, and had sent letters to the fisheries authorities claiming that vessels with mobile gear fished up local fish stocks and left their traditional fishing grounds empty (Bull 2011). The Porsanger fjord was the scene of numerous conflicts between Sami small-scale fjord fishers and Danish seiners fishing for cod in the early 1980s, where the latter were accused of overfishing the limited and vulnerable cod resources in the fjord (Nilsen 1998; Eythorsson 2008). The predicament of small-scale fjord fishers in Porsanger was particularly important as a background for the development of Sami fisheries policies after 1990, where larger quotas and prioritization of small-scale vessels was a central part of the policy.

This analysis of small-scale fisheries transformation in Porsanger is first done through an analysis of the actual number of vessels in Porsanger and their characteristics in the vessel registry kept by the Director of Fisheries between 1950 and 2001 ${ }^{\mathrm{a}}$ (Vessel Registry 19212001), and then through closer analysis of selected fishers' vessel careers in the same period. The fishers' vessel careers are based on interviews with fjord fishers regarding their local ecological knowledge (LEK) conducted by the Fávllis ${ }^{\mathrm{b}}$ research project, and three field visits to Porsanger during 2009 and 2010 to conduct map-based interviews. ${ }^{c}$ Following Johnsen et al. (2009a, 2009b) and Neis and Felt (1999), this article makes use of vessel career interviews which have the advantage of bringing chronological order through focusing on vessel shifts as an organising principle of a fishers' career. Vessel shifts in several individuals' careers are followed to create an image of general changes in larger fishing 
assemblages over time. A map component was also added to the interviews to add more insight into the spatial aspects of fishing activities rather than focussing only on LEK gained in interaction with one specific ecological or technological niche. Map biographies (Tobias 2010) were created ${ }^{\mathrm{d}}$ to visualise changes in fishers' movements and use patterns in the seascape. The fishers' and vessels' real names are given as the article is not meant to represent the whole group of fishers in Porsanger or indigenous fishers in general (Smith 2005), but also take into account diversity and individual choices in the analysis of general trends in coastal Sami small-scale fisheries.

\section{Sami fishing vessels and the vessel registry}

Descriptions of traditional Sami fishery adaptations often use the situation in the period prior to the Second World War as a starting point. In the beginning of the 1900s, Sami fishers in general used common wooden, open vessels (Nordlandsbåt) with or without sails that varied in length between 5 and 15 meters, depending on their use. Sami fishers in Finnmark were integrated in the Pomor trade network, but lost access to the Russian markets when the network collapsed prior to the First World War. The Norwegian government starting from 1905 issued financial support through various loan funds to increase the use of modern and motorized vessels, which resulted in an increase in multi-crew, larger motorized fishing vessels (skøyte, generally between 13 and 23 meters). In the post-war period, building up a modern fisheries industry based on filet factories and freezing technology was central in the plans to rebuild coastal communities in the north of Norway which had been destroyed during the war (Finstad 2005). As Finnmark had been subject to the "scorched earth" policy by German troops in 1944, thousands of vessels had been destroyed, along with infrastructure such as landing centres, fish racks, and industrial facilities. Larger vessels had been used in the evacuation and resettlement of the population in Finnmark, and were immediately after the war put to use as fishing vessels. The policy was to transform fishing into a commercial occupation and employ the coastal population as workers in the fishing industry, and a production facility in Honningsvåg, close to Porsanger, was in operation to receive fish in the early 1950s. Investments in vessels, gear, and favourable fish prices for the fishers were subsidised by the state and formalised in the Main Agreement between the state and the Norwegian Fishers' Association from 1964. The availability of cheap outboard engines and financial support through state loan funds and the Fishers' Bank resulted in a large increase in the number of motorized fishing vessels, and in small-scale fisheries in general. According to several sources however, Sami who combined fishing with farming were less eligible for such funds and were easily out competed (NOU 2008:5; Gjerde and Mosli 1985). State support to the fisheries industry was, prior to the 1990s, increasingly criticised for contributing to over-capacity that lowered the profitability of the industry. Almost at the same time as the IVQ system was introduced in 1990, state support for the industry was abandoned and market liberalism was introduced, with dire consequences for small-scale Sami fisheries (Sami Parliament 2004). The situation before 1990 and material consequences of the processes post-1990 can be seen through the Fisheries Director's biannual vessel registry.

The registry recorded the vessels' names, their owners, vital measures such as the year vessels were built, when they were rebuilt, what kind of engines they had, radio communication, their construction material, and whether they were open or covered 
vessels. In addition to being a registry that allowed for the state to see and control vessels, the registry in the beginning functioned as a way for the industry to advertise their services, as reflected in the presence of a wealth of advertisements for engines, equipment, echo sounders and fishing gear in the publications of the 1950s and 1960s. Whether vessels were open or decked was one of the main categories in the registry. An open vessel was defined as a vessel without any cover, steering house or sleeping compartment (Director of Fisheries 1990). (In general, covered vessels in the registry range from around 6.7 meters and upwards, while open vessels are smaller than 7.5 meters, although examples of open eight-meter vessels and covered five-meter vessels are also to be found). Most vessels registered in Finnmark in the beginning of the 1950s were decked vessels while under half were registered as open vessels, and most were motorized with outboard or built-in engines. The number of open vessels increased from 1950 to reach a maximum of 4000 vessels before it started decreasing around 1970. In the rest of the country the same pattern can be seen, but the decrease in open vessels started ten years earlier in the south of Norway than in the north (Maurstad 2008).

\section{The Porsanger Fjord}

In the Porsanger 1950 vessel registry, there were only four open vessels out of a total of 45 vessels registered, where the smallest one measured 6.25 meters (20 feet) and the largest around 12 meters. Most of the 45 vessels were decked, multi-crew vessels registered for participation in fjord fisheries, while a few were registered for coastal fisheries. From 1952 to 1966, the registry contains information about which vessels had installed echo sounders aboard. In 1952, out of 56 vessels only the 10 meter long vessel 'Alken' owned by Berner Sivertsen in Smørfjord was registered with an echo sounder. In 1966 four vessels had an echo sounder. The low number of echo sounders in the 1960s was a general occurrence also in the neighbouring municipalities and not special to Porsanger. Larger vessels appear late in the registry, such as the 31 meter 'Porsangergutt' built in 1969 and with an engine of $550 \mathrm{hp}$, registered in 1986 to an owner in Indre Billefjord.

As illustrated in Figure 1, the number of registered open vessels (typically wooden motorized boats below seven meters) increased dramatically between 1950 and 1966

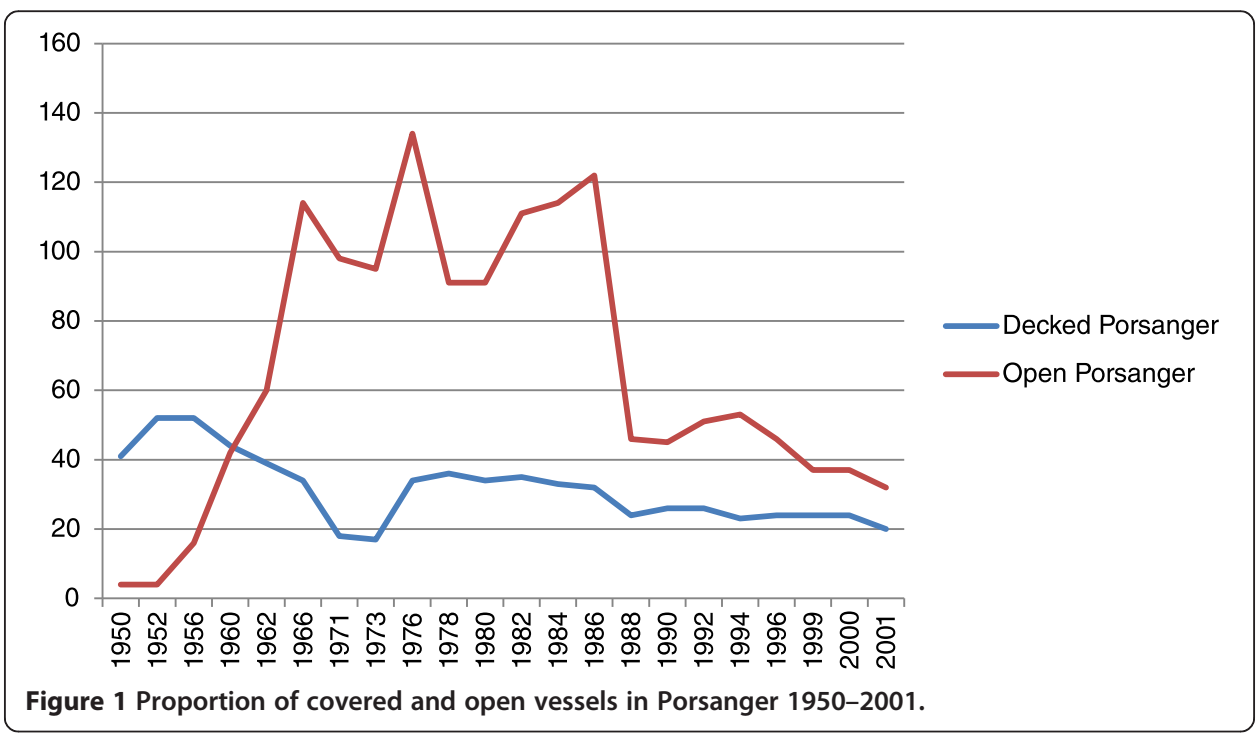


from four to 114 vessels, while the number of decked vessels was reduced. The sharp increase in open vessels from 1950 onwards follows the same development as the rest of the county, and consisted of new open vessels with outboard engines. In contrast to the rest of Finnmark however, Porsanger did not experience a decrease in the number of open vessels until the 1988 registry, when it was dramatically reduced by fifty percent (Figure 1). The larger, decked vessels tend to decrease in the same period.

The introduction of the individual vessel quota (IVQ) system in 1990 made a rather minor impact on the number of vessels compared to the drop in 1988. The number of quotas allocated to the Porsanger fishers was however very low compared to coastal areas, as only 22 out of 71 vessels achieved a vessel quota based on the required amount of catch during the years 1987 to 1989 . This was explained as a consequence of the so-called 'seal invasion', which was a sharp increase in the number of harp seals in northern Norwegian fjords at the end of the 1980s leading to increased cod mortality, and therefore lower catches and cod quotas for fjord fishers (Eikeland 1994). The number of fishers in Porsanger between 1990 and 2005 was reduced by $75 \%$ to only around 20 fishers, the most dramatic development of all the fjord municipalities in Finnmark (Maurstad 2008).

The analysis of the vessel registry shows that out of the 71 vessels registered in 1990, there were 26 covered and 45 open vessels in Porsanger. It is reasonable to assume that the decked vessels represented greater opportunities for larger fish catches, and that most of these were among the lucky 22 that received a quota in 1990. The most disadvantaged group seems to be the group of fishers that disappeared during the seal years. The vessel registry thus shows that it was a certain type of vessel in Sami small-scale fisheries that suffered the consequences of the introduction of the quota system. In 2013, there were 34 registered vessels in Porsanger, out of which 11 were registered with cod quotas. These were all between 8.5 and 10.65 meters, and the smallest vessel registered only 5.3 meters. In comparison, none of the vessels registered in 1950 in Porsanger measured below 6.25 meters. The idea of the traditional Sami small-scale fishery is thus perhaps not so far from the current policy of protection of fisheries conducted with vessels of 11 meters or less.

The different trajectories in the group of small, open vessels with outboard engines in Porsanger relative to the country and Finnmark in general indicates that something facilitated small-scale fjord fisheries in Porsanger in the period between 1970 and 1988 when it was decreasing in the rest of Finnmark as a whole. State support has already been mentioned as a factor that increased the number of fishing vessels in general in the post-war period, while the forces driving fishers towards profit maximization resulted in a transformation of the fishing fleet into fewer and larger vessels (Johnsen 2005; Standal and Aarset 2002). In Porsanger, this development does not seem to take effect until the late 1980s, which may indicate that fishers with small, open vessels managed to maximize their profit in a period when these were out competed elsewhere by larger and more sophisticated vessels. In the next section, examples of three different fishing assemblages through fishers' vessel careers are presented to investigate how social, materialand ecological conditions influenced fjord fisheries in the post-war period.

\section{Porsanger vessel careers}

A look at the composition of the vessel fleet in Porsanger reveals that the fjord is not 'one place', but is constituted by different communities where some are more active in 
terms of participation in fisheries than others. Fisheries are generally conducted by fishers from the communities around Smørfjord and Indre Billefjord (see Figure 2). In the 1976 registry as an example, almost 70\% of the vessels in Porsanger were registered to this area, with 58 of the in total 168 vessels registered to Indre Billefjord alone and with no marked difference in the proportion of open or decked vessels registered to one or the other community. Most of the remaining fishing activity today is however concentrated around Smørfjord where the only remaining landing station is located. The next sections are organised around the careers of Ragnar Samuelsen and Arnulf Andersen from the Billefjord area, and Roald Wilhelmsen from Smørfjord.

\section{Ragnar Samuelsen}

Ragnar Samuelsen was born in 1937 in Indre Billefjord and experienced the dramatic evacuation during the Second World War, as well as the rebuilding of his home and community. As a 17-year old, Ragnar started working as crew on one of the decked vessels in

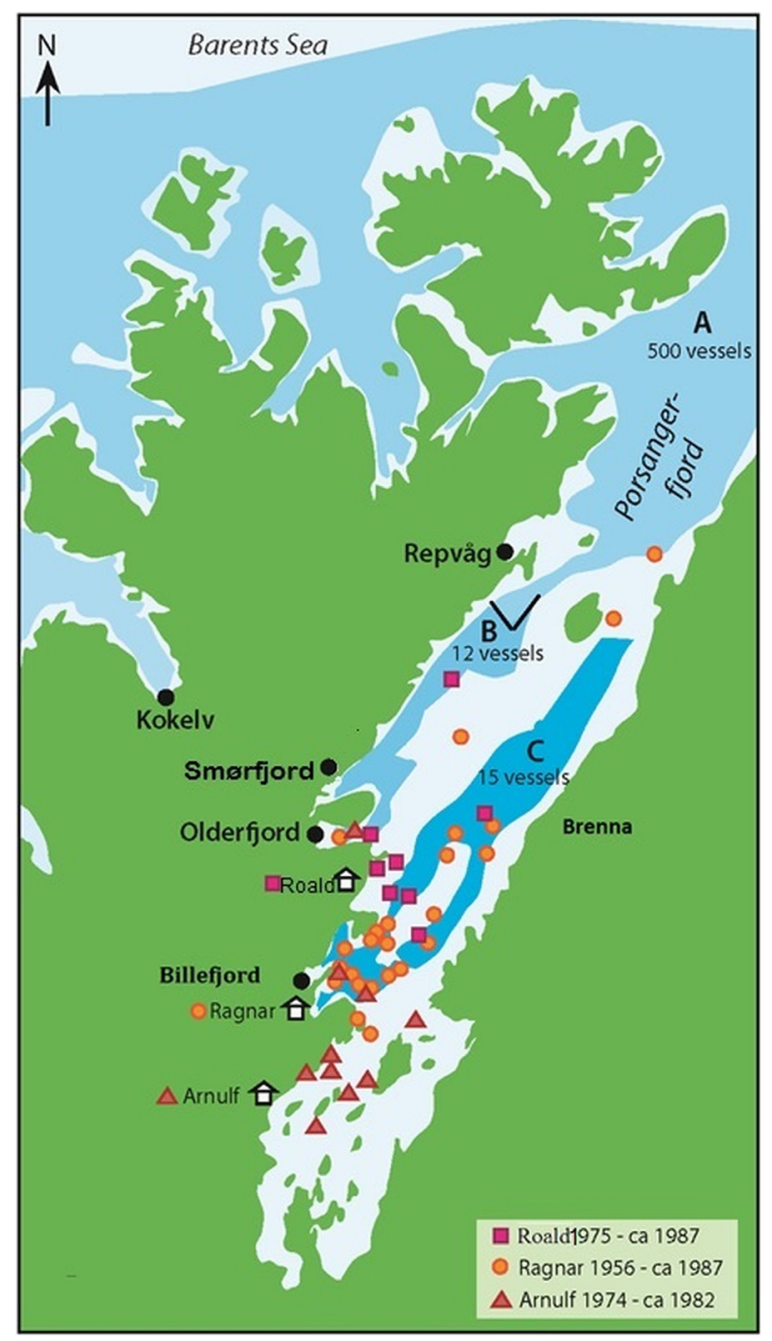

Figure 2 Overview of named fishing grounds in Porsanger. Fishing grounds used prior to 1990 mapped from fishers' vessel career interviews. Passive gear use areas mapped by the Directorate of Fisheries in 2007 (areas A B and C), based on interviews with fishers. Map by Frøydis Strand, Norwegian College of Fishery Science. 
a neighbouring fjord. Ragnar recalls the time when new gear and fish net types were introduced to the fishery: 'In 1954 we were in Refsbotn, which was the first year we got hold of nylon nets'. The nylon nets were more expensive than the old thread nets, and to finance them, fishers needed to maximize their income from the fisheries. According to Ragnar, there were not enough fish in the Porsanger fjord at time to support fjord fisheries until the beginning of the 1960s. Ragnar fished occasionally between paid work in the construction sector, and running a small farm in Indre Billefjord together with his wife Else until 1967. From then on, his main activity was connected to fjord fisheries. In 1966 Ragnar is registered in the vessel registry with the 17 foot (five meter) open boat 'Draug', built in 1948 and rebuilt in 1962, with a small motor of $3 \mathrm{hp}$. His wife started educating herself at the beginning of the 1970s, and functioned as her husband's accountant and partner in the fishing enterprise at the same time as they raised their children.

In 1972, he bought his own 11.3 meter boat 'Lillefjord' together with other fishers in Billefjord and started fishing on the fishing grounds in the inner part of Porsanger, delivering fish to the newly opened fish buyer Bull in Billefjord. 'We all fished. Those years people bought boats and skimmed the cream. Those were the seventies when there were a lot of fish in here', Ragnar recalls. The fishery was mainly conducted during the winter and early spring, concentrated around the Olderfjord area. In 1980, Ragnar Samuelsen is registered as the owner of the $9.5 \mathrm{~m}$ decked boat 'Jan Tore'. The registry for 1982 shows that Ragnar is registered as the owner of the open boat 'Lita' of only 4.9 meters, and 'Jan Tore' now belonged to someone else. According to Ragnar, catches had already started to decrease, and at the same time as he sold his boat and Else started working away from home, he became more and more engaged in the work of the Billefjord fishers' association. Following conflicts with active gear type vessels, the fishers repeatedly appealed to the Finnmark Fishers' Association that the Porsanger fjord should be closed for Danish seiners. Ragnar fell increasingly ill in the middle of the 1980s and stepped down his career as a commercial fisher, only keeping the boat 'Lita' for the occasional fishing trip.

\section{Arnulf Andersen}

Arnulf Andersen was born in 1956 and started working as a 16-year old with the fish buyer Bull in Indre Billefjord, before he started fishing in 1974 with his own small vessel on the grounds in the innermost part of the fjord. He was not registered as an owner in the vessel registry, but used a family boat for fishing for saithe with nets in the autumn and for cod during winter and early spring. Arnulf described the fishing grounds in the area as places where particularly large cod and saithe around $10-15$ kilos came to spawn and feed. Arnulf delivered his fish to the fish buyer for a few years. The fish however stopped coming to the grounds starting in the late 1970s. 'The big saithe, the Porsanger saithe we used to call it, it was gone, I think it was in 1977 when the big boys caught the last bit of the Porsanger saithe, a little over 100 tons they took in the fjord and since then no one has seen it any more'. In 1980 he participated as a crew member on two of the larger, covered vessels from Indre Billefjord, which numbered 15 out of the 34 covered vessels in Porsanger at that time. The fish buyer in Indre Billefjord was in operation until the early 1980s, when it closed down due to a decrease in landings. Arnulf blamed the fjord fishers' own effort on the cod stock in Olderfjord for the decrease. 


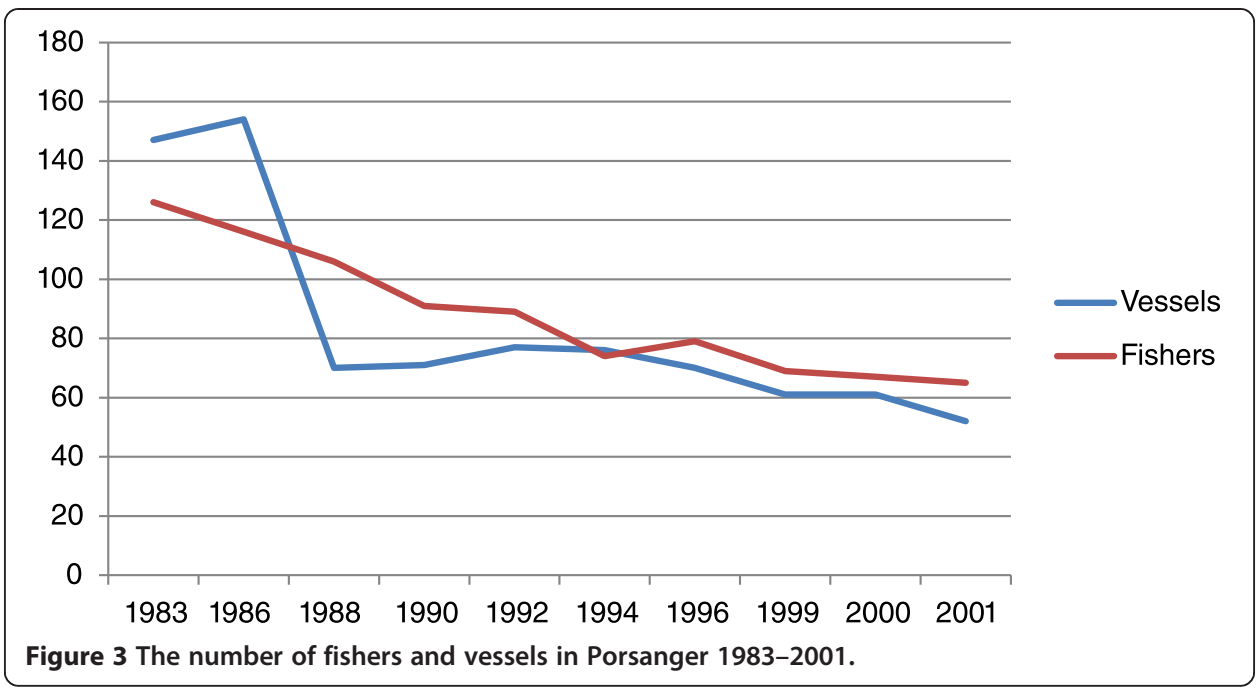

The main season was there [in Olderfjord]. From January on to the end of the spring fisheries. There were so many nets there that when you came driving around and looked in Olderfjord it was like a cloudberry field. It was orange with gill net buoys. And that was the spawning fish they took, or we took, I was of course part of it too.

Other interviews with fishers from this part of the fjord confirm that catches had started decreasing already in the late 1970s, due to overfishing by both Danish seiners and the increasingly effective fjord fishers' fishing effort on limited fishing grounds. Maurstad and Sundet (1998) marked the Billefjord area as a dead spawning ground in a survey of coastal cod and North East Arctic cod spawning grounds in Finnmark. The Olderfjord area was also marked off as an abandoned ground, which according to the Porsanger fishers occurred with the seal invasion.

In 1982, when he was in his early twenties Arnulf quit his career as a fisher and started education as a teacher. Arnulf's exit from the fisheries coincided with the end of the inner part of the fjord as a stable basis for fish catches. The same decrease in the number of vessels cannot however be seen until the late 1980s (see Figure 3). Together with the small increase in the number of small-scale open vessels in the early 1980s, this indicates that vessels abandoned by fishers such as Arnulf and Ragnar stayed circulating among existing fishers or fisher families, as the next narrative will illustrate.

\section{Roald Wilhelmsen}

Whereas Ragnar and Arnulf belonged to the group of fishers that disappeared prior to 1990, Roald Wilhelmsen (born in Kistrand in 1957) was part of the group that stayed. As part of a family of fishers, his vessel career had already been prepared. His father Marelius Wilhelmsen was born in the 1930s and had fished on six different vessels throughout his career. In the 1976 registry, Marelius is fishing together with his sons Roald and Bernt from the 7.6 meter covered vessel 'Lamøy', registered as owned by his son Bernt. Roald and his father and brother were able to bring in larger catches despite the declining size of the fish from the middle of the 1970s. In 1984, Bernt Wilhelmsen and crew turn up as the owner of another and larger vessel, Havdønn of 11.3 meters, while 'Lamøy' figures in the registry on the same owner until it was sold and turns up 
with a new owner in the 1986 registry. The change from the $7.6 \mathrm{~m}$ 'Lamøy' to the 11.3 meter 'Havdønn' meant an increase in capture capacity and horse power, which enabled the crew to increase their effort in the fjord fishery. Roald Wilhelmsen also blamed on Danish seiners' overexploitation of the fishing grounds for the decreasing catches, but also saw their own use of smaller mesh in the gill nets as a contributing factor. With investments in new fishing gear and the increasingly common use of echo sounders and newer fish finding equipment, the way that Roald and the crew onboard 'Havdønn' fished and used the seascape changed. This involved shifting fisheries from slopes to deeper areas as the new nets were deeper and the echo sounders found fish where they had not fished before. 'After a while we discovered that there were fish down at the mud bottom as well, and there were even more fish. But the old people just used the grounds and the slopes when they fished', Roald explained.

In 1985 Roald established himself with his wife in Smørfjord and started his own enterprise for preparation of smoked salmon based on the local sea-based salmon fishery which many combined with cod fisheries. While he was busy with the enterprise and family, he registered the boat 'Wilhelm' - a new, open boat of 5.3 meters with a $40 \mathrm{hp}$ engine that he occasionally fished with. In 1987, the seal invasion had a dramatic effect on the local cod stock that used to spawn in the Olderfjord area and which up until then had been the main fishing area for the fjord fishers. The 'Havdønn' crew managed to keep up a certain level of activity, by among other things shifting their fishing area to deeper waters on the eastern side of the fjord, but also by reducing their crew members. Others were not so lucky, as Roald explained:

We fished a little and hoped that the fish would come in, but all of the nets were destroyed by the seals. There was some compensation, and most fished to have some income, but then we moved out of the fjord. All of the boats moved to Honningsvag, Repvåg and further away. Most of the fjord fishers quit fishing then.

Together with the sharp drop in open vessels in the vessel registry, this explains the vulnerability of the group of open vessels, and how the decked vessels were able to achieve a quota in 1990. Figure 2 illustrates how fishers abandoned first the inner part of Porsanger, and then the middle part, as the cod ceased to return to the spawning grounds in Billefjord and Olderfjord due to overfishing and seal predation. The remaining fishing areas are indicated by the A, B and C field, mapped by the Directorate of Fisheries in 2004.

Roald bought his own boat in 1991and managed to achieve a vessel quota in the closed group. The boat 'Jim Levi' of 9.5 meter is registered in the 1992 registry, which shows a small increase in the number of small vessels of around five meters. Among these small boats is a vessel belonging to a woman in the Wilhelmsen family. Roald stationed his vessel in the neighbouring fjords Repvåg and Kokelv (see Figure 2) together with other fishers from Porsanger looking for more stable ecological conditions. With long hours spent driving to the boat, shorter time on the fishing grounds, loans on the vessel with the quota and family obligations, Roald and his wife decided to quit their business in 1993. Roald continued fishing for cod, and from the turn of the century also for king crab, which had spread from Russia and exploded in numbers in Finnmark fjords in the late 1990s.

In 2000, out of 61 vessels in the registry, 7 of these had been in operation in the 1978 registry. One of the covered vessels (out of three) was 'Lamøy', which in 1978 had been Bernt's boat. In 2000, the vessel registry contained Roald and his vessel 'Jim Levi', Bernt 


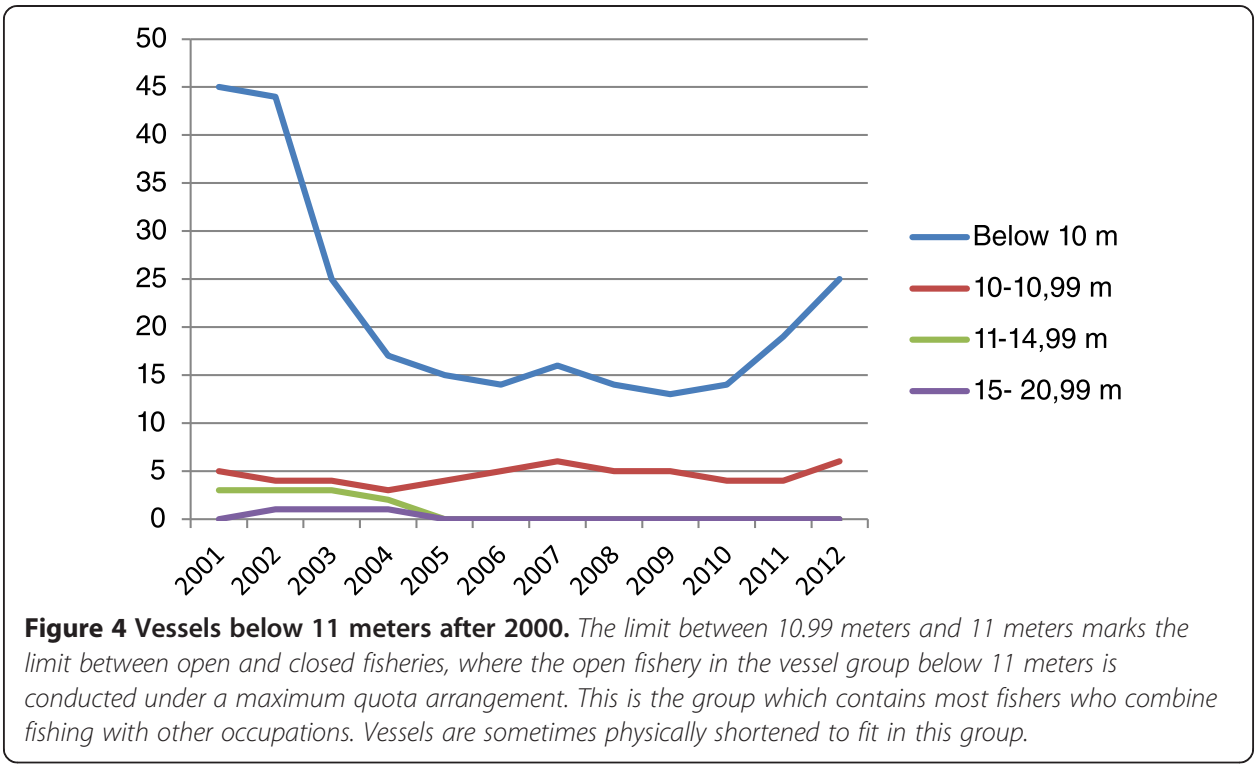

with 'Havdønn', as well as one of the younger sons of the Wilhelmsen family who were registered with two smaller vessels of 8 meters each, one open and one covered. As illustrated by Figure 4, most of the remaining decked vessels in the period after the turn of the century in Porsanger are between 10 and 10.99 meters (Directorate of Fisheries 2013). The vessels have become equipped with the latest in fish-finding technology using digital sea charts and sonars, and both Roald and Bernt are currently among the most active fishers in Porsanger. Bernt later (from 2012 to 2014) was the leader of the Sami fishing association 'Bivdi', founded in 2004.

Many of the vessels that disappeared from the registry were decommissioned and ended up in various states of disintegration on the shores of Porsanger, as is illustrated by the diversity of boat wrecks and vessels in Figure 5. Some of the older decked vessels have stayed fishing and are still in operation along with smaller leisure boats, while new and modern vessels have been put out of the fishery along with the open and wooden vessels of the post-war period.

\section{Discussion}

Based on the career narratives of Roald, Arnulf, Ragnar, their families, and the circulation of their fishing vessels in the larger collective of fishers and vessels in Porsanger, it can be stated that Sami small-scale fisheries are affected by what Johnsen et al. (2009a, 2009b) call processes of cyborgization that have taken place in Finnmark, Norway and the North Atlantic in general. Cyborgization is most clearly demonstrated by the fact that the large number of small open boats that were so prevalent until the middle of the 1980s have been replaced with fewer and larger vessels. However, when analysed as a collective of fishers and vessels, it has become evident that a diversity of factors also contributed to this development, which contains sudden twists and turns that cannot be explained by the cyborgization process alone. In addition to large-scale changes in governance structures and steering mechanisms, ecological changes and the agency of the larger assemblage of fishers and vessels in the fjord played roles in the transformation of small-scale fisheries prior to 1990. 


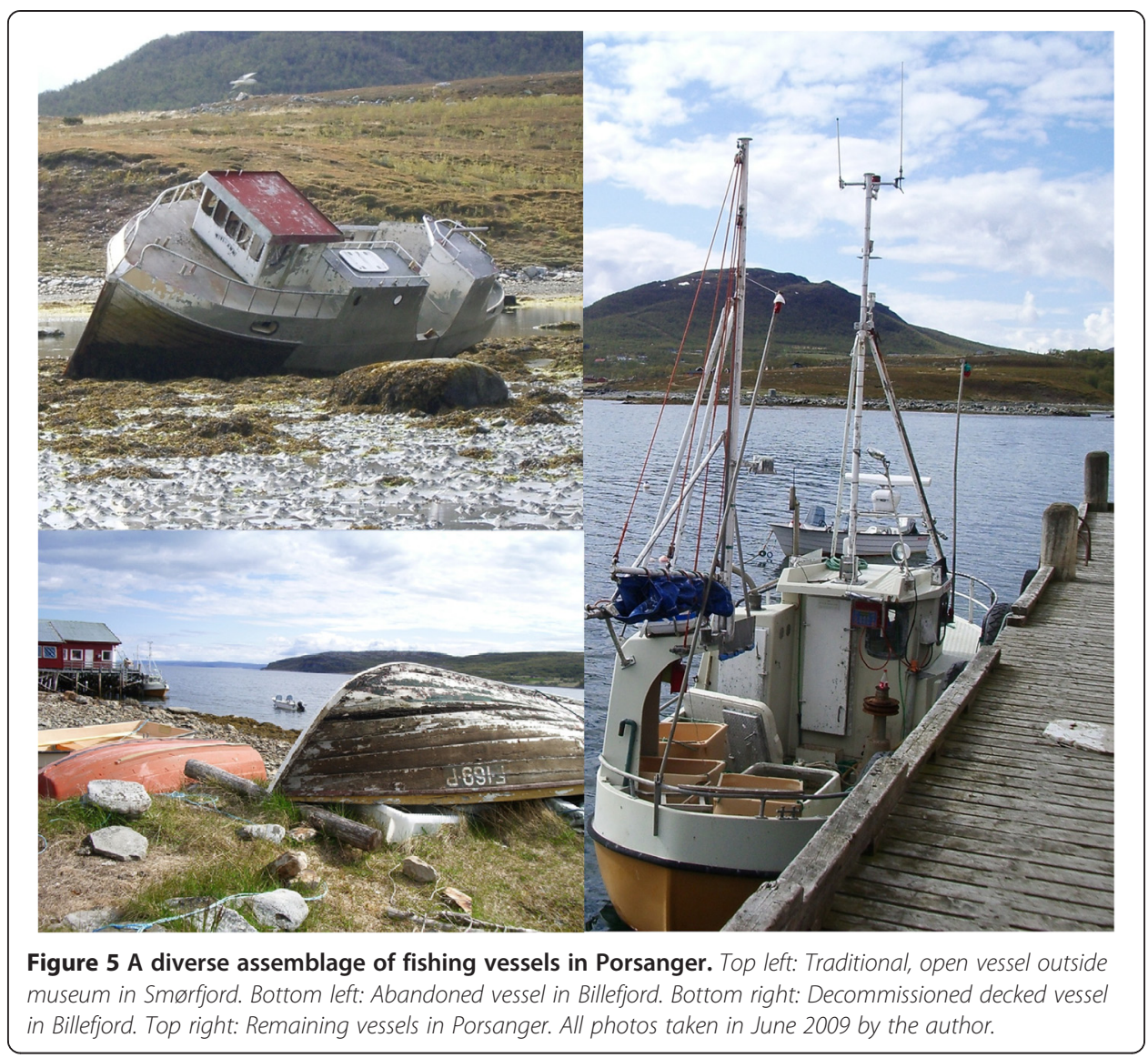

\section{Ecological intensification among small-scale fishers}

As the map biographies illustrate, the fishing effort of the interviewed fishers was concentrated in the inner part of the fjord until the cod stocks disappeared from the Olderfjord area. This means that local fishers contributed substantially to overfishing of local stocks together with the Danish seine fishery between the early 1960s and the middle of the 1980s in Porsanger. In this period, the small, open vessels with cheap outboard engines were without a doubt the preferred vessel of choice. As told by Ragnar Samuelsen, for fishers to spend the whole season fishing on fishing grounds in the fjord was not an option until the 1960s and 1970s, partly because the cod became more abundant, and partly because of rising fish prices and increasing efficiency of the fishing gear. The increase in the number of open vessels came mainly in the inner and middle part of the fjord, close to spawning grounds which were later (in a study by Maurstad and Sundet 1998) registered as abandoned coastal cod spawning grounds.

According to Neis and Kean (2003), if fishers intensify and expand their fisheries along spatial, temporal and ecological axes, this implies that a fish stock collapse may be imminent. Small-scale fishers' intensification and expansion aided by technological innovations, as well as few regulatory measures to balance fishing pressure relative to the resource base are also factors contributing to ecological degradation (Neis and Kean 2003). The increase in the number of fishers and vessels in the post-war period in Porsanger is an indication that fishers did expand and intensify their effort on relatively limited fishing grounds where the local cod stocks spawned. As the interview with Roald shows, this 
happened concretely in Porsanger through the fishers' expanding effort from the shallow grounds and slopes of the fjord, to bottom areas. Moreover, all fishers mention the large amount of fishers using the same fishing grounds, the decreasing mesh sizes, and the Danish seiners' overexploitation of the Porsanger cod. Since vessels were not commonly equipped with fish-finding equipment, it seems that the use of local knowledge of fishing grounds and the traditional landmark system in Porsanger (see Brattland and Nilsen 2011) was a sufficiently efficient technology for this intensification. The seasonal pattern of the fishery as a part of the total household economies may also have resulted in an intensification of the fishers' effort during a limited period of time.

The decreasing fish sizes signalled overexploitation of local cod stocks prior to the seal invasion, which explains why cod stocks did not recover after the 1987 seal invasion. Maurstad (2000) argues that it was the management regime's lack of restrictions which caused the general cod crises in the late 1980s. Since fishers were fishing under an in-essence open access fishing regime before 1990, overexpansion and overfishing of the total allowable catch (TAC) occurred, which again led to fewer fishers and a limited number of quotas after 1990 (Maurstad 1997; Maurstad 2000). Development of overcapacity was evident in the Norwegian fishing fleet in general prior to the cod crisis due to more and larger vessels, as well as improved and more efficient technology aboard the vessels (Standal and Aarset 2002). In Porsanger however, although overfishing did occur by the combined fleets of open, decked and active gear vessels, ecological conditions were the direct cause for the disappearance of the resource base for the local fjord fishers in the middle of the 1980s. In addition to the seal invasion and overfishing, Larsen (2010) indicates that changes in sea temperature may have contributed to the disappearance of local, discrete stocks of cod in the Porsanger fjord. The same sudden decrease in cod catches was not evident in other fjords in Finnmark or in coastal fisheries in general. This strongly suggests that fjord fishers in the innermost part of Porsanger exploited discrete resources that were relatively unconnected to the resources fished by coastal fishers and which the fishers with decked vessels had access to from other ports.

The existence of local and discrete stocks of cod in fjords along the Norwegian coast has since become verified and is currently included in stock assessments and management advice (Berg and Albert 2003). Based on these findings, it can be argued that what many perceived as a traditional coastal Sami fishery with small vessels and simple gear adapted to stable ecological conditions was much more complex. In the post-war period, fjord fisheries defined as a fishery on discrete local resources conducted with open vessels were fisheries in a process of expansion, facilitated by a complex mix of factors such as favourable ecological and managerial conditions.

\section{Transformation in small-scale fishing assemblages}

Johnsen et al. (2009a, 2009b) focus on how individual fishers make choices within certain frameworks. This position as part of larger networks governed by central powers reduces the social agency of fishers. Developments in technology, changes in selfregulating systems and forms of knowledge that fishers employ when switching modes are used to describe the general development of the cyborgization process. How much of a role did individual and collective choices of fishers and their families play in how the larger collective of fishing assemblages in Porsanger developed? Similar to fishers who switched from one form of knowledge to another in both Newfoundland and 
Norway (Johnsen et al. 2009a, 2009b), Sami fishers in Porsanger made transitions from local knowledge to digital fish-finding equipment, and towards tighter integration in larger networks such as quota and management regulations, during their careers. However, not all fishers make such transitions in the same ways, or keep up the same kind of activity during their careers. Maurstad (1997 and 2000) documented different fisher adaptations within the northern Norwegian coastal fishery, ranging from the household-based seasonal fisher to the full-fledged, profit maximizing fisher. Lillevoll (1998) and Nilsen (1998) also document general switches in technology related to different stages in a man's life cycle, where the youngest and oldest fishers use smaller vessels and cheaper technology than the middle-aged fishers. Based on their needs, fishers with high debts fish more than fishers with low debts, and fishers with larger vessels may fish less than fishers with smaller vessels depending on their family situation or career stage. Fishers also switch between vessels depending on the stage of their careers and their general family situation and spouse's income. Capture capacity is thus not only decided by switches to more sophisticated vessels, but also dependent on the fishers' partial or full utilisation of that technology, varying with his or her needs and social circumstances. Like Ragnar Samuelsen and Marelius Wilhelmsen, many vessel owners in the vessel registry in Porsanger switched from larger to smaller vessels at the end of their careers, while other family or community members continued fishing with the vessels that were most suited to their career stage. As fishers change their needs and career priorities over time, fishing assemblages continue to fish and are in operation as long as there is a new fisher to replace the previous one. This is largely in keeping with Johnsen's (2005) concept of the robo-fisher as a position in a network of relations, but without evolution towards an effective harvest machinery.

There is also much to support the idea that fishers continually adapt to new governance systems and technological systems by incorporating new knowledge, technology and routines into their practices, and not only in transitions from mechanistic to cybernetic modes. Ragnar Samuelsen went through similar shifts in technology and adapted by utilising new technology and gear already in the 1960s, and Roald Wilhelmsen utilised knowledge passed on to him from his father that might be described as equally sophisticated as radars and sonars. There are also local variations in the degree to which vessels fleets are modernized. The vessels utilised throughout Ragnar Samuelsen's career illustrate that technology on board vessels changed little from the initial instalment of motors and net haulers on the open vessels in the 1960s, and the registry shows that very few vessels contained echo sounders. The fact that wooden, small vessels without echo sounders stayed fishing for more than 40 years in the Porsanger fjord can be interpreted as a sign that they served well the needs of the fishers that used them during changing governance regimes and ecological conditions. Contrary to popular belief there was a majority of decked vessels over seven meters in Porsanger in 1950, and most of the smaller, open vessels that dominated the fjord fishery between the early 1960s and 1990 were new vessels built in the post-war period. The proportion of decked vessels, with the possibility for installation of echo sounders, powerful gill net haulers and other equipment, however stayed relatively stable.

Many fishers thus stayed with the same technology through changing social, ecological and economic contexts, perhaps because it served their needs, or perhaps because fisheries was only a seasonal occupation from which they could choose to enter and exit, like 
Arnulf Andersen did. If a fisher switched to another vessel or upgraded the old one with new parts and technology, the previous vessels and old technology were still somewhere in the system, perhaps taken over by a younger or older fisher. This continuity was made possible through fisher families' previous and ongoing participation in fisheries in Porsanger all through the post-war period. Where Roald Wilhelmsen had the experience, capital and the position inherited from his father that was necessary to make the next technological switch to survive the seal invasion and the quota introduction, many others fell behind. This illustrates that depending on the level from which fishers start, the entrance into fisheries networks is different, and fishers carry different assets and agencies. From a livelihoods perspective, assets such as social and economic capital are seen as central in a systems' capability to recover from stress (its resilience) (Allison et al. 2001). Both this and the peasant mode of production perspective (Chayanov 1966) imply the existence of a stable social community impacted by external social-ecological events. Judging from the Porsanger fishers' different adaptations through history from trading with the Pomor, through their own reflections on their contribution to the disappearance of the local cod stocks in Porsanger, the impression is rather one of continual and flexible transformation. Also, the geographical and temporal differences in the development of small-scale fisheries in Norway at large, in Finnmark in general and in Porsanger are evidence of diversity and variation that is not necessarily limited to some modes or historic periods. Recent turns in economic theory have opened up approaches that recognise the existence of economic hybridity and diversity, instead of locking economic development onto linear trajectories relative to 'capitalist hegemony' or in conceptions of western and 'Third World' economic inequalities (Gibson-Graham 1995; St. Martin 2001; St. Martin 2005; St. Martin, McCay et al. 2007; Gibson-Graham 2008; Graham and Roelvink 2010). Similarly, instead of an inevitable transformation into cybernetic harvest machineries then, a more diverse and heterogeneous fisheries system that includes mixtures of 'organic' and 'cybernetic' fishing assemblages can be imagined.

The same can be said of the categorization of the cyborgization process into different historical modes, which are produced as separate modes through how one type of relation is cast as 'the other' in relation to the next. The prevalence of small and open vessels in Sami fjord fisheries for a period of time entered a position as 'the other fishery' against which other fisheries were measured. Likewise, vessels running on steam and coal may seem like sophisticated cyborgs compared to vessels with sail and oar technology. But just as the steam boat's position became replaced by motorized vessels, so may the current cyborg vessels' position be filled by other types of fishing assemblages, for instance in a future or episteme (Foucault 1970) where fossil fuel-driven fisheries are not facilitated. The end of the current cyborg vessels' position is perhaps already suggested by the way decommissioning of superfluous vessels to deal with overcapacity may put even new and 'sophisticated' vessels out of business (cf. Figure 5). As the case presented here illustrates, fishers and vessels thus entered and left positions and relations in diverse assemblages in the Porsanger small-scale fishery.

\section{Conclusion}

This article has argued that small-scale fisheries are transforming, but not necessarily being eradicated as a rural livelihood in industrialised contexts. It is appealing to adopt the 
description of development from the 'organic' mode of fisheries associations towards the cybernetic as a valid trajectory of development for traditional Sami small-scale fisheries of the past. Following this line of thinking would explain how Sami small-scale fisheries are dwindling and integrated into the modern, cybernetically organised fishery of the present. There is however more research to be done regarding the extent to which this general trend is valid across historical and geographical contexts, as well as across social, material and ecological conditions. Even though the current fisheries governance system since the 1990s has been increasingly characterized by cybernetic relations (Johnsen et al. 2009a), there is also a movement towards rights-based protection of certain vessel groups and fisheries such as in Norway and in global networks (FAO 2011). This article has investigated diverse trajectories of different groups of vessels and fishers behind the general statistics that show decreasing numbers of small-scale vessels and accumulation of fishers and catches on larger and fewer vessels. Based on an empirical analysis of vessel registries and vessel career interviews of a group of fishers in Porsanger, continuity and even growth in the group of open fishing vessels have been documented, while the group of decked, coastal fishing vessels has remained relatively stable.

The disappearance of the small-scale fjord fishery that in many contexts has been represented as a traditional adaptation among Sami fishers is partly supported by the analysis. However, the main finding is that fjord fisheries with open vessels and outboard engines in Porsanger experienced an enormous growth in the period between the early 1960s and the middle of the 1980s, and that fisheries with decked coastal fishing vessels remained relatively stable over that period. This was supported by favourable economic and ecological conditions, until local cod stocks were overfished both by local and foreign vessels, and the fjord fishery was abruptly ended with what was termed an 'invasion' of seals to the Finnmark coast in the mid-1980s. With the introduction of the quota system in 1990, almost all of the vessels in the decked, stable group in Porsanger were able to acquire a quota. In the case of the Porsanger fjord fishery, this article has illustrated that small-scale fisheries are always in a process of change and transformation, and that it consists of a diversity of fishing assemblages that may or may not be facilitated by governance systems and how fisheries systems transform. Thus, there may still be a future for Sami small-scale fisheries in cybernetic fisheries systems, even though not all of the adaptations that were facilitated by favourable conditions in the past are suitable for the present and future fisheries. As this article has illustrated, integration of small-scale fisheries into larger and cybernetic networks thus need not mean its eradication, even though it is being transformed.

\section{Endnotes}

'The Director of Fisheries' vessel registry (Vessel Registry 1921-2001) is available from 1950 to 2001 as written reports, and from 2001 onwards as a digital, searchable registry. The statistics referred to by Johnsen (2013) are digitally available only from 1983 onwards and prior to that in paper form. Data from the registry investigated for the purposes of this paper have been manually entered into Excel forms by the author. The owners of the vessels had to pay a fee to have the vessel registered in the registry, which makes the registry dependent upon actions taken by the owners. Maurstad (2008) in her discussion of coastal fisheries in Finnmark in the Coastal Fisheries' 
Commission's report (NOU 2008:5) points out that the vessel registry is not a good measure of activity and does not accurately reflect the number of vessels that fished, but rather registers how many own and register their vessels in the registry. The registry does thus not accurately represent the number of active vessels in Porsanger in the period, but it can be assumed that a majority of the registered vessels were active.

${ }^{\mathrm{b}}$ Fávllis is a Sami word referring to a deep and open part or fishing area in the sea, as opposed to a shallow fishing ground. It is a multi-year Sami fisheries research network organized by the Centre for Sami Studies at the University of Tromsø, supported by the Norwegian Research Council. This paper draws on the common data collection and fieldwork done in Porsanger for the Fávllis project.

${ }^{c}$ Through the Fávllis project, a total of 19 fishers and locals resource users (15 men and 4 women between 40 and 70 years of age) from settlements on the western shore of the Porsanger fjord were interviewed between 2008 and 2010. The interviews are stored in a project interview database, which was organised and coded using NVivo 9, which is a software for the analysis of qualitative data. Coding of interviews was done according to pre-decided categories organised according to social-ecological periods and events in the social-ecological history of the fjord, in addition to analytical categories that emerged from the texts during analysis (Glaser, B. G. and A. L. Strauss (1977). Among the categories were named fishing grounds, which made possible aggregation of several fishers' activities taking place at the same fishing ground at the same time, as well as temporal changes. Fishers' activities on the same fishing grounds were combined with each other to produce a general social-ecological narrative of a fishing area.

'Local sea charts used by fishers were used during the interviews to map fishers' mobility through their careers in points which were then digitized and entered into a geographical information system (GIS), thereby creating a map illustrating fishers' responses to socio-ecological change over time. The movements of the fishers in the seascape were then compared with the Norwegian Directorate of Fisheries' recent surveys of fishing areas in the Porsanger fjord in general as part of a national marine habitat mapping program (Directorate for Nature Management 2007), based on information from local fishers' associations.

Competing interests

The author declares no competing interests.

\section{Acknowledgements}

This article was initially submitted as part of the doctoral thesis 'Making Sami Seascapes Matter. Ethno-ecological governance in coastal Norway' (Brattland 2012) with the title 'Overfishing and cyborgization in Sami fisheries. A study of small-scale fisheries in the Porsanger fjord, northern Norway'. Thanks are due to the Coastal Sami Resource Centre in Porsanger, Ragnar Samuelsen, Roald Wilhelmsen and the fishers of Porsanger for making this study possible. Thanks are also due to the comments offered on early drafts of the article from Bjørn-Petter Finstad, Svein Jentoft and Svanhild Andersen, as well as Signe Annie Sønvinsen. A special thank you to Jahn Petter Johnsen who inspired and commented on the article along the way. The views and statements expressed in this article are however the author's own. The finalisation of the article was made possible with strategic research funding from the Norwegian Institute for Cultural Heritage Research (NIKU).

Received: 12 November 2014 Accepted: 12 November 2014

Published online: 11 December 2014

\section{References}

Allison, EH, and F Ellis. 2001. The livelihoods approach and management of small-scale fisheries. Marine Policy 25(5): 377-388. Berg, E, and OT Albert. 2003. Cod in fjords and coastal waters of North Norway: distribution and variation in length and maturity at age. ICES Journal of Marine Science. Journal du Conseil 60(4): 787.

Bjørklund, I. 1991. Property in Common, Common Property or Private Property: Norwegian Fishery Management in a Sami Coastal Area. North Atlantic Studies 3(1): 41-45.

Brattland, C. 2012. Making Sami Seascapes Matter. Ethno-ecological governance in coastal Norway. PhD thesis, Faculty of Biosciences, Fisheries and Economics. Tromsø: University of Tromsø. 
Brattland, C, and S Nilsen. 2011. Reclaiming Indigenous Seascapes. Sami Place Names in Norwegian Sea Charts. Polar Geography 34(4): 275-297.

Broderstad, EG, and E Eythórsson. 2014. Resilient Communities? Collapse and Recovery of a Social-Ecological System in Arctic Norway. Accepted in Ecology and Society, special issue to be published in 2014.

Brox, O. 1969. Recruitment and Organizational Stability in Industrially Underdeveloped Areas: Some Aspects of the Problem of Industrialization in the Cod-Fishery of North Norway. Acta Sociologica 12(1): 20-28.

Brox, O. 1984. Nord-Norge. Fra allmenning til koloni. Oslo: Universitetsforlaget.

Bull, KS. 2011. Kystfisket i Finnmark: en rettshistorie. Oslo: Universitetsforlaget.

Chayanov, AV. 1966. Peasant farm organization. The theory of peasant economy, 29-278.

Davis, A, and S Jentoft. 2001. The challenge and the promise of indigenous peoples' fishing rights-from dependency to agency. Marine Policy 25(3): 223-237.

Deltakerloven. 1999. Lov om retten til å delta i fiske og fangst (deltakerloven). [Act of particiation in the fisheries]. Entered into partcipation 2000-01-01. Oslo: Ministry of Fisheries and Coastal Affairs.

Director of Fisheries. 1990. Register over registrerte fartøy i Norge 1990 [Registry of registered vessels in Norway 1990]. Bergen: Fiskeridirektoratet

Directorate for Nature Management. 2007. Kartlegging av marint biologisk mangfold -DN-håndbok 19 2001, revidert 2007. Trondheim: Direktoratet for naturforvaltning.

Directorate of Fisheries. 2013. Statistikkbank. Fartøyregisteret. [Statistics bank. Registry of registered vessels in Norway] http://www.fiskeridir.no/register/fartoyreg/. Accessed 2013 - 01-09.

Eikeland, S. 1994. Moderne selinvasjonar. [Modern seal invasions]. Ottar 201: 15-18. Tromsø University Museum.

Eythorsson, E. 1993. Sami fjord fishermen and the state: traditional knowledge and resource management in northern Norway. In Traditional Ecological Knowledge: Concepts and Cases, ed. J Inglis, 132-142. Ottawa: International Development Research Centre.

Eythorsson, E. 2008. Sjøsamene og kampen om fjordressursene. Karasjok: Čálliid Lágadus.

FAO. 2011. International Guidelines on Securing Sustainable Small-Scale Fisheries. Rome: FAO.

Finstad, B-P. 2005. Finotro: statseid fiskeindustri i Finnmark og Nord-Troms : fra plan til avvikling. Tromsø: Institutt for historie, Det samfunnsvitenskapelige fakultet, Universitetet i Tromsø: V, 367 s.

Foucault, M. 1970. The Order of Things. New York: Pantheon. part II.

Gibson-Graham, J. 1995. Identity and economic plurality: rethinking capitalism and 'capitalist hegemony'. Environment and Planning D: Society and Space 13(3): 275-282.

Gibson-Graham, J-K. 2008. Diverse economies: performative practices for other worlds'. Progress in Human Geography 32(5): 613-632.

Gjerde, A, and JH Mosli. 1985. Samiske næringers plass i samfunnsplanlegginga. Guovdageaidnu [Kautokeino]: Sámi instituhtta. Guovdageidnu: Sami instituhtta.

Glaser, BG, and AL Strauss. 1977. The discovery of grounded theory: Strategies for qualitative research. Chicago: Aldine Publ.

Graham, J, and G Roelvink. 2010. An economic ethics for the Anthropocene. Antipode 41(s1): 320-346.

Haraway, DJ. 1997. Modest-witness@ second-millennium. Femaleman [Copyright]-meets-oncomouse [Trademark]: Feminism and Technoscience. Routledge, New york: Psychology Press.

Hidle, K, J Cruickshank, et al. 2006. Market, commodity, resource, and strength: Logics of Norwegian rurality. Norsk Geografisk Tidsskrift - Norwegian Journal of Geography 60(3): 189-198.

Jentoft, S. 1993. Dangling lines : the fisheries crisis and the future of coastal communities : the Norwegian experience St. John's: Memorial University of Newfoundland, Institute of Social and Economic Research.

Jentoft, S (ed.). 1998. Commons in a cold climate: coastal fisheries and reindeer pastoralism in North Norway: the co-management approach. Man and the biosphere series. 22: 121-144Paris. New York: Unesco Parthenon.

Johnsen, JP. 2005. The evolution of the 'harvest machinery': why capture capacity has continued to expand in Norwegian fisheries. Marine Policy 29(6): 481-493.

Johnsen, JP. 2013. Is fisheries governance possible? Fish and Fisheries (14).

Johnsen, JP, P Holm, P Sinclair, and D Bavington. 2009a. The Cyborgization of the Fisheries: on Attempts to Make Fisheries Management Possible. MAST 7(2): 9-34.

Johnsen, JP, GD Murray, and B Neis. 2009b. North Atlantic Fisheries in Change. From Organic Associations to Cybernetic Organizations. MAST 7(2): 55-82.

Larsen, TH. 2010. Population dynamics of cod, Gadus morhua, in Porsangerfjord, Northern Norway: analysis of back-calculated length at age from otoliths in 1992 and 2009. Master thesis, faculty of Biosciences, Fisheries and Economics. Tromsø: University of Tromsø.

Latour, B. 1993. We have never been modern. Cambridge: Harvard Univ Pr.

Latour, B. 2005. Reassembling the social-an introduction to actor-network-theory. Oxford: Oxford University Press.

Lillevoll, TA. 1998. Open Commons for Fjord Fishery in Coast Saami Areas? In Commons in a cold climate. Man and the biosphere series, vol. 22, ed. S Jentoft, 121-144.c. Paris New York: Unesco Parthenon.

Marine Resource Act. 2009. Lov om forvaltning av viltlevande marine ressursar (havressurslova). Entered into force 200901-01. Oslo: Ministry of Fisheries and Coastal Affairs.

Maurstad, A. 1997. Sjarkfiske og ressursforvaltning. Institutt for samfunns- og markedsfag, Norges fiskerihøgskole. Tromsø: Universitetet i Troms $\varnothing$.

Maurstad, A. 2000. To fish or not to fish: small-scale fishing and changing regulations of the cod fishery in Northern Norway. Human organization 59(1): 37-47.

Maurstad, A. 2008. Fiskerinæringas økonomiske og kulturelle betydning for befolkningen i Finnmark. In NOU 2008:5 Retten til fiske i havet utenfor Finnmark. Oslo: Fiskeri-og kystdepartementet.

Maurstad, A, and JH Sundet. 1998. The invisible cod-fishermen's and scientists' knowledge. In Commons in a Cold Climate. Coastal Fisheries and Reindeer Pastoralism in North Norway: the Co-management Approach: 167-184. Man and the biosphere series, ed. S Jentoft. Paris New York: Unesco Parthenon.

Minde, H. 2005. Assimilation of the Sami: implementation and consequences. Kautokeino: Resource Centre for the Rights of Indigenous Peoples. 
Neis, B, and LF Felt. 1999. An interdisciplinary method for collecting and integrating fishers' ecological knowledge into resource management. In Fishing places, fishing people: traditions and issues in Canadian small-scale fisheries, ed. D Newell and R Ommer, 217-238. Toronto, Bufallo, London: University of Toronto Press Incorporated.

Neis, B, and R Kean. 2003. Why Fish Stocks Collapse: An Interdisciplinary Approach to the Problem of 'Fishing Up'. Toronto: University of Toronto Press.

Nilsen, R. 1998a. The Coastal Survivors - Industrialization, Local Adaptations and Resource Management in the North Norwegian Fisheries. In Commons In a Cold Climate, Man and the Biosphere series vol, vol. 22, ed. $\mathrm{S}$ Jentoft, 83-96. Unesco Parthenon: Paris New York.

Nilsen, R. 1998. Fjordfiskere og ressursbruk i nord. Oslo: Ad notam Gyldendal.

NOU. 2008. 5. Retten til fiske i havet utenfor Finnmark. Oslo: Fiskeri-og kystdepartementet.

Parliament, Sami. 2004. Sametingets melding om fiske som næring og kultur i kyst- og fjordområdene. Karasjok: Sametinget.

Smith, LT. 2005. Decolonizing methodologies: Research and indigenous peoples. London: Zed books.

Søreng, SU. 2008. Fishing rights discourses in Norway: indigenous versus non-indigenous voices. Maritime Studies 6(2): 77-99.

Søreng, SU. 2013. Legal pluralism in Norwegian inshore fisheries: differing perceptions of fishing rights in Sami Finnmark. Maritime Studies 12(9).

St. Martin, K. 2001. Making space for community resource management in fisheries. Annals of the Association of American Geographers 91(1): 122-142.

St. Martin, K. 2005. Mapping economic diversity in the First World: the case of fisheries. Environment and Planning A 37(6): 959-979.

St. Martin, K, BJ McCay, et al. 2007. Communities, knowledge and fisheries of the future. International Journal of Global Environmental Issues 7(2): 221-239.

Standal, D, and B Aarset. 2002. The tragedy of soft choices: capacity accumulation and lopsided allocation in the Norwegian coastal cod fishery. Marine Policy 26(3): 221-230.

Tobias, T. 2010. Living Proof: The Essential Data-Collection Guide for Indigenous Use-and-Occupancy Map Surveys. Vancouver: Ecotrust Canada and UBCIC.

Vessel Registry (1921-2001). Register over merkepliktige norske fiskefarkoster. Fiskeridirektoratet. Available at http:// brage.bibsys.no/xmlui/handle/11250/129388.

Yin, RK. 2009. Case study research: Design and methods. Los Angeles: Sage Publications, Inc.

doi:10.1186/s40152-014-0018-1

Cite this article as: Brattland: A cybernetic future for small-scale fisheries. Maritime Studies 2014 13:18.

\section{Submit your manuscript to a SpringerOpen ${ }^{\circ}$ journal and benefit from:}

- Convenient online submission

- Rigorous peer review

- Immediate publication on acceptance

- Open access: articles freely available online

- High visibility within the field

- Retaining the copyright to your article

Submit your next manuscript at $\boldsymbol{\nabla}$ springeropen.com 